DOSSIÊ

\title{
O objeto obsceno do fascismo
}

\author{
The obscene object of fascism \\ Soulo pinto*
}

DOI: https://doi.org/10.4322/principios.2675-6609.2021.161.005

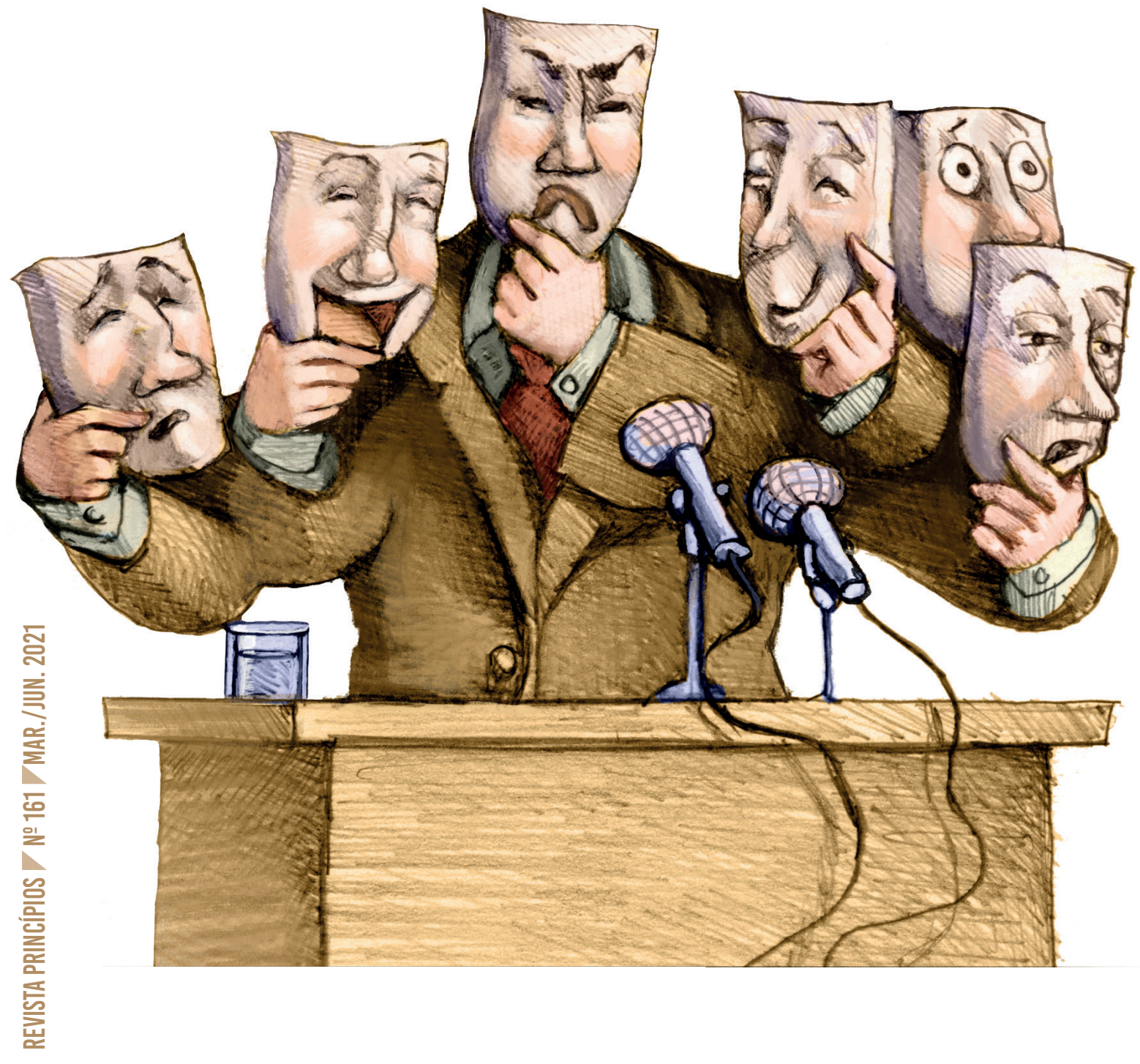

$\underline{80}$ 


\section{RESUMO}

O ensaio discute a atualização da noção de fascismo, não como uma anomia para o capitalismo e a democracia, mas pensando sua obscenidade como manifestação das ambiguidades do sistema dominante. Assim, intento formular uma elaboração sobre a relação entre despolitização, crise da esquerda e ressurgimento do fascismo contemporâneo, combinando aspectos da conjuntura e sua relação substancial com a estrutura. Por fim, enuncio o conceito de fascismo democrático, baseado na elaboração do filósofo Alain Badiou, combinado com pequenos apontamentos sobre a instituição de uma orientação alternativa ao ordenamento capitalista e ao fascismo, o que, nesse caso, significaria a produção de um gozo para fora do capitalismo.

Palavras-chave: Capitalismo. Democracia. Fascismo.

\section{ABSTRACT}

The idea of my essay is to discuss the updating of the notion of fascism, not as an anomy within capitalism and democracy, but thinking of its obscenity as a manifestation which reveals ambiguities in the inner of the dominant system. Thus, I try to formulate an elaboration concerning the relationship between depoliticization, the crisis of left-wing and the resurgence of contemporary fascism, combining aspects of the conjuncture and its substantial relationship with the structure. Then, I enunciate the concept of democratic fascism, from the elaboration of the philosopher Alain Badiou, combined with brief notes on the institution of an alternative orientation to capitalist order and fascism that, in this case, would mean the production of an enjoyment out of capitalism.

Keywords: Capitalism. Democracy. Fascism. 


\section{INTRODUÇ̃̃O: O GOZO OBSCENOI DA LACUNA}

O fascismo é tradicionalmente tratado como uma anomia, ou mesmo traduzido como desequilíbrio, da democracia. No limite, diante da impossibilidade de tratá-lo como algo próprio ao desenvolvimento contraditório da democracia, ele é tratado como um objeto que interdita a vida democrática. É possível que o fascismo seja um bloqueio ao desenvolvimento da democracia? Ou estamos lidando hoje com um tipo de fascismo que não apenas não é antitético à democracia — deixando de funcionar como uma razão interna e insuficiente dela —, como de alguma maneira faz parte do seu momento constitutivo? O objeto obsceno do fascismo aparece quando o seu conteúdo latente precisa ser realizado no conteúdo manifesto da democracia.

No entanto, não é correto tratar fascismo e democracia em um quadro de similitude sublime, portanto, completamente impróprio ao excesso ontológico constitutivo que sustenta a lacuna substancial. Temos que pensar que o fascismo é uma reação pseudotransformativa, pois ele busca restaurar a manutenção da desigualdade objetiva (lacuna) existente diante do fracasso da democracia. A questão decisiva é que a democracia é produzida tentando-se preencher, ou substituir, a lacuna ontológica que a política democrática não é capaz de ocupar. Primeiro com Hegel, depois com Marx, a "dessemelhança" é o elemento que tem a capacidade de captar a incompletude da "realidade objetiva", ou seja, o excesso objetivo produzido não pode ser propriamente realizado na forma-política capitalista. A questão da forma não é menor, pois o desafio é pensar quais são as condições para que o conteúdo latente fascista possa aparecer na forma manifesta da democracia como política. Nesse sentido, como sugeriu Evguiéni Pachukanis, "temos a obrigação de averiguar o que essa forma particular gerou de novidade" (PACHUKANIS, 2020, p. 26). Não estamos diante desse desafio hoje?

Jacques Rancière fala em "ódio à democracia" pensando o paradoxo da democracia, que não pode sobreviver sem a agitação popular ao mesmo tempo que repele todo excesso propriamente democrático. O paradoxo é que "a política é o fundamento do poder de governar em sua ausência de fundamento", pois a "democracia ingovernável" somente pode aparecer numa tensão interna explosiva. Assim, "a democracia não é nem uma sociedade a governar nem um governo da sociedade" (RANCIÈRE, 20I4, p. 66). Temos de pensar aqui a homologia entre a existência da "democracia ingovernável" e a "realidade objetiva" do capitalismo ingovernável. Com efeito, não se trata de um problema meramente político, mas da existência de uma lacuna objetiva incômoda que não pode ter solução duradoura na mudança do controle do metabolismo social.

1 Utilizo a noção de obscenidade para caracterizar o objeto do fascismo hoje, quando a relação entre a democracia e o fascismo vem sendo absolutamente obliterada e traduzida ideologicamente como algo repulsivo, sujo, escandaloso, no intuito de manter uma certa distância impermeável entre ambas: a democracia funciona sempre como o avesso e o antídoto ao fascismo. No entanto, o objeto obsceno do fascismo só pode funcionar hoje por dentro da democracia liberal sob a condição de que essa relação se mantenha sempre não declarada. Slavoj Žižek sugere que "um segredo obsceno" é sempre aquilo que "não deve ser admitido publicamente", pois "esse segredo absoluto é uma mentira" (ŽIŽEK, 2013, p. 80). 


\section{De alguma maneira, o litígio possível hoje é entre as tentativas de politização e as denegações da política}

A admissão, por parte dos democratas, de sua cumplicidade com o fascismo é uma impossibilidade que transforma o objeto num segredo obsceno, ou seja, a relação subjacente jamais pode aparecer publicamente. É por isso que o fascismo existe sempre como um espectro atormentando a "normalidade" da democracia. A democracia acusa o fascismo pelo caos antidemocrático, e o fascismo acusa a democracia de ser uma pseudodemocracia das elites. Talvez seja justamente essa falsa simetria que define a cumplicidade objetiva entre ambos. Como diz Slavoj Žižek, "nunca deveríamos subestimar o poder das aparências. Por vezes, quando perturbamos inadvertidamente as aparências, a própria coisa que está por trás delas também se despedaça" (ŽIŽEK, 20Io, p. 35-36). Não é assim que deveríamos tratar hoje a aparência (falsa) de antagonismo entre democracia e fascismo?

O objeto obsceno do fascismo é uma tentativa, ainda em elaboração, de pensar o curto-circuito do despedaçamento da (falsa) aparência do antagonismo entre a democracia limitada que temos hoje e o fascismo. A subjetividade regressiva que dá corpo ao fascismo não vem antes da subjetividade artificial que dá corpo à democracia. Na verdade, ela vem depois, como uma espécie de complementação obscena à subjetividade democrática atuante. O resultado é a própria transgressão da obediência (democrática), constituindo um tipo de gozo obsceno (perverso) da lacuna. Nesse caso, o fascismo que experimentamos é resultado da incapacidade da democracia em resolver a lacuna aberta na constituição ontológica do capitalismo. É nesse sentido que Adorno é mobilizado aqui, pois ele foi capaz de perceber - com antecipação notável —, que o verdadeiro perigo não é a existência do fascismo contra a democracia, mas sua constituição e atuação dentro da democracia. O objeto obsceno do fascismo é uma tentativa de atualização de uma teoria crítica do fascismo que pense seu funcionamento dentro (e não fora) da democracia.

Para tanto, discutiremos primeiro (item 2) a construção da antipolítica e da lógica policial que medeiam o desenvolvimento das condições objetivas para que o fascismo surja. Tentaremos demonstrar como a democracia atual interdita a plena representação popular, ou melhor, o capitalismo produz uma parte dos sem parte que não encontra incorporação no pleno funcionamento da democracia e isso é o que cria os distúrbios sociais explosivos que vão ser capturados pelo discurso fascista. Em seguida (item 3), tentaremos apresentar uma interpretação do fascismo contemporâneo, discutindo a noção imanente do fascismo - como um constructo lógico, político e filosófico - até alcançar a noção atualizada de "fascismo democrático" tal 
como elaborada por Alain Badiou. Essa noção é decisiva, pois parte da ideia de que o fascismo contra a democracia é uma idealização que não corresponde à forma efetiva do "fascismo democrático" que atua dentro da democracia. Por fim (conclusão), tentaremos esboçar pequenos e provisórios lineamentos teóricos de um gozo para fora do capitalismo como uma modalidade autêntica de enfrentamento do capitalismo e sua democracia oligárquica e (propriamente) de transgressão ao fascismo que existe dentro da democracia.

\section{ANTIPOLIITICA E LÓGICA POLICIAL}

Em tempos propriamente obscuros, a questão que marca o impasse estrutural básico é: ainda é possível um acontecimento propriamente político? O capitalismo global, além de ser um modo de produção que produz exploração econômica, traduz a dominação social abstrata em formas concretas e sensíveis de dominação política e humilhação social. É assim que, de alguma maneira, o litígio possível hoje é entre as tentativas de politização e as denegações da política. Não seria esse um conflito decisivo no quadro mais aberto dos conflitos universais? É necessário retomar aqui Jacques Rancière, quando diz que "a instituição da política é idêntica à instituição da luta de classes” (RANCIÈRE, 20I8, p. 33).

A questão é que a luta de classes não pode ser tratada como expressão das contradições objetivas do capitalismo, mas aparece como a própria forma de existência dessa contradição. A política precisa ser pensada como problema, e não apenas como manifestação aparente de algo que está oculto. Nesse sentido, Žižek comenta $a$ noção de política em Rancière:

O que é, na realidade, para Rancière, a política? Um fenômeno que, pela primeira vez, apareceu na Grécia antiga quando os membros do demos (os que não se beneficiavam de qualquer posição claramente determinada no edifício social hierarquizado) não reclamaram apenas que as suas vozes fossem ouvidas contra os que detinham o poder, exerciam o controle social — não protestaram apenas contra a injustiça que sofriam e não exigiram apenas que as suas vozes fossem ouvidas, reconhecidas como fazendo parte da esfera pública, em pé de igualdade com a oligarquia e a aristocracia dominantes -, mas, muito mais do que isso, quando os excluídos, que não se beneficiavam de qualquer justo lugar no interior do edifício social, se apresentaram como os representantes, os porta-vozes da sociedade no seu conjunto, em nome de uma autêntica universalidade ("Nós — os 'sem-parte' —, que não somos tomados em conta na ordem social, somos o povo; estamos todos juntos contra aqueles que não defendem mais do que os seus interesses privilegiados particulares.") (ŽIŽEK, 2006, p. 33-34).

Dito isso, temos de tratar a política não apenas como a forma aparente das relações objetivas subjacentes, mas precisamos pensar a política como o domínio 
próprio do conflito. Para os poderes dominantes é necessário que a ordem dos lugares sociais e que o campo simbólico dos falantes se mantenha num certo nível de controle, pois a subjetividade atua imediatamente sobre as condições da objetividade existente. Então, a desigualdade não é apenas um lugar de assimetria objetiva, mas ordena e disciplina o campo propriamente simbólico da imaginação e da subjetividade atuante. É funcional ao campo dominante que o realismo seja o limite último do horizonte de expectativas compartilhado. Além disso, é necessário estabelecer a desigualdade como uma espécie de dano interno ao ato em si, sem nenhuma relação com o sistema dominante, isto é, as tentativas de despolitização da desigualdade objetivam obliterar o dano, para que ele jamais apareça na forma do incorrigível litígio da luta de classes. Isso significa que o curto-circuito decisivo está sempre entre a particularidade e a universalidade, ou seja, a classe da dominação precisa aparecer como representante direta da universalidade de todos no universo social ideológico dominante.

Lembrando Hegel, o impasse da sociedade burguesa está em equacionar o curto-circuito entre a particularidade e a universalidade, quando cabe "à universalidade o direito de mostrar-se como fundamento e forma necessária da particularidade" (HEGEL, 20Io, p.I89). Entretanto, a particularidade não pode simular a universalidade, ou seja, a emancipação somente é completa quando dissolve a própria particularidade como alternativa em si mesma. É assim que Marx insiste que "a emancipação política ainda não constitui o modo já efetuado, isento de contradições, da emancipação humana" (MARX, 20Io, p. 38, grifos originais).

O dano que está na existência objetiva do conflito - ou do litígio, nos termos de Rancière - significa que uma parte substancial do corpo social não pode ser incorporada ao sistema econômico, ao mesmo tempo que não tem lugar plenamente reconhecido na ordem simbólica do mundo. Ou melhor, seu lugar é apenas o de não ter lugar algum que mereça alguma consideração significativa. Hegel elabora uma fecunda caracterização do "desigualitarismo" produzido pelo sistema de carecimentos, quando diz que "a queda de uma grande massa [de indivíduos] abaixo da medida de certo modo de subsistência, que se regula por si mesmo como o necessário para um membro da sociedade", "produz o engendramento da populaça" (HEGEL, 20IO, p. 223, grifos originais).

Nesse sentido, a populaça é o conteúdo latente explosivo do capitalismo e de sua democracia política. Para utilizar um termo de empréstimo (e complexo) da psicanálise, a desigualdade é sintoma do funcionamento "normal" do capitalismo. Não é que algo vai mal - como uma anomia que precisa ser corrigida ou eliminada -, mas é que a desigualdade produzida pelo capitalismo está em pleno acordo com seu funcionamento ontológico, que aparece permanentemente na sua "normalidade”. É necessário perceber que a desigualdade não é reprimida: ela é incorporada ao "realismo capitalista", pois "ele não é, portanto, um tipo particular de realismo; é o realismo em si” (FISHER, 2020, p. I3).

Assim, ao contrário do credo puramente ideológico que funciona como falsa consciência, a populaça é a corporificação da desigualdade (ou dessemelhança) que 
não pode ser eliminada, mas apenas controlada por meio de sua incorporação ideológica no funcionamento da dominação social. O que temos aqui é a tradução política do curto-circuito subjacente ao capitalismo, em que particularidade e universalidade estão em permanente discordância. Para Žižek:

Em resumo, o conflito político designa a tensão entre o corpo social estruturado, dentro do qual cada parte ocupa o seu lugar, e a afirmação de que "há uma parte dos sem-parte" que vem abalar essa ordem em razão do princípio de universalidade vazio, daquilo a que Balibar chama de igualiberdade, a igualdade de princípio de todos os homens enquanto seres dotados de palavra. O próprio da política induz sempre, portanto, uma espécie de curto-circuito entre o universal e o particular: o paradoxo de um singular universal, de um singular que aparece como o substituto do universal, repondo em questão a ordem funcional "natural" das relações no interior do corpo social. Essa identificação dos sem-parte com o todo, da parte da sociedade que é desprovida de lugar verdadeiramente justo dentro dela (ou à qual repugna aceitar o lugar de segunda categoria que dentro dela lhe é concedido) com o universal é o gesto elementar da politização, detectável em todos os grandes acontecimentos democráticos [...] (ŽIŽEK, 2006, p. 34, grifos originais).

Nesse sentido, toda política antidemocrática se caracteriza pela interdição das energias verdadeiramente democráticas, isto é, o desejo latente inscrito na política antidemocrática sempre funciona na direção do regresso à ordem normal das coisas. Grosso modo, a regressão política e social tem uma dimensão estritamente reacionária. Isso significa que a orientação da política antidemocrática está na tentativa de que os lugares sociais e a ordem dos falantes sejam restabelecidos pela restauração do poder dominante. É assim que o poder dominante atua para que o conflito decisivo seja invisibilizado, ou melhor, deslocado de sua causa autêntica mediante um tipo de distorção ideológica fundamental. Na verdade, a distorção aparece como a nova realidade objetiva. Com efeito, a "normalidade" restituída não pode ser reparada por um espaço simbólico-racional de comunicação, como quer Habermas, pois qualquer legitimidade aqui significa uma luta duradoura de forças antagônicas e hostis.

Contraditando a separação entre "mundo da vida" e "sistema" operada por Habermas, Robert Kurz vai dizer que "os 'democratas radicais' de esquerda de diferentes tendências separam as promessas democráticas de sua forma econômica de mercado e opõem externamente as duas faces do processo de modernização". O resultado é uma ilusão - não no sentido de que o "objeto" em questão não existe, mas de que limita a percepção —, que permite a pressuposição de que "a democracia deveria ser, supostamente, o oposto do capitalismo” (KURZ, 2020, p. 25).

A solução democrática, então, será sempre impotente para a resolução do antagonismo ontológico. Diante do "desigualitarismo" objetivo que está corporificado na existência da populaça, a única ordem possível de reparação do dano se dá median- 


\section{A economia é traduzida como um conjunto de relações estranhas ao ordenamento social abrangente, que não podem ser controladas ou mobilizadas pela subjetividade e pela política}

te a luta. Todavia, Hegel politiza o conflito, dizendo que a pobreza em sua imanência não transforma ninguém em populaça, pois "esta aparece somente com a disposição que se associa à pobreza, com a íntima indignação contra os ricos, a sociedade, o governo etc." (HEGEL, 1999, p. 359, tradução nossa). A fórmula política é a seguinte: não é a imanência objetiva que institui a populaça, mas propriamente a disposição do (e para o) conflito. É o desejo em atuação que produz a subjetividade radical.

O que temos de perceber aqui é que a despolitização quer interditar o conflito decisivo antes mesmo que o conflito possa se manifestar como política, ou seja, evitar que a divisão constitutiva do povo possa ser politizada. Nesse sentido, diz Rancière, "a soberania popular é uma maneira de incluir o excesso democrático, transformar em arché o princípio anárquico da singularidade política — o governo dos que não têm título para governar" (RANCIÈRE, 20I4, p. 97, grifos originais).

A questão que importa é justamente essa. $\mathrm{O}$ excesso democrático precisa ser contido pelo poder dominante, pois é necessário combater - no campo da antecipação da imaginação política — a possibilidade de que aqueles "que não têm título para governar" aspirem ao poder de governo. O desejo como política precisa ser reprimido imediatamente. Evidentemente, é a ideologia que tem a capacidade de exercer essa tarefa política fundamental do combate por antecipação, instituindo o desejo na máquina interna do "realismo capitalista": mais uma vez, o "sistema" e o "mundo da vida" fazem parte da mesma dinâmica global de dominação social. Nesse caso, o "oposto", ou seja, a democracia, está posto no regime de "normalidade" capitalista.

Todavia, essa equação não diminui a complexidade da relação. A questão difícil ainda é a apreensão da relação entre capitalismo e democracia. Trata-se de uma equação explosiva que implica a reprodução das relações apolíticas de dominação, dado que as relações objetivas nunca são tratadas como relações que podem ser objeto da operação política. Na verdade, a economia é traduzida como um conjunto de relações estranhas ao ordenamento social abrangente, que não podem ser controladas ou mobilizadas pela subjetividade e pela política. 
O "desigualitarismo", nesse caso, é destituído de qualquer imagem especular da ordem dominante. Ele precisa ser traduzido permanentemente como um desvio interno da "normalidade" propriamente capitalista. O que precisamos nos perguntar é: existe realmente a possibilidade de termos democracia com a existência do "desigualitarismo" objetivo? Ao contrário da hipótese do "estado de exceção", que "marca um patamar onde lógica e práxis se indeterminam e onde uma pura violência sem logos pretende realizar um enunciado sem nenhuma referência real" (AGAMBEN, 2004, p. 63, grifos originais), o que temos é a dominação social determinada, que se dá por meio do fetichismo do "sistema sem sujeito" (KURZ, 2020, p. 27), que aparece na economia de mercado, mas também na dominância de classe. É importante lembrar aqui Maurizio Lazzarato, para quem "a democracia sempre foi compreendida pelos liberais como democracia dos possessores”. Ele segue insistindo que:

Eles sempre conceberam os direitos como indexados à propriedade. Foram as revoluções que impuseram a igualdade e conquistaram os direitos políticos e sociais "para todos". Uma vez desfeita a revolução e constatada a incapacidade das forças anticapitalistas de reorganizá-la, a democracia logicamente desapareceu. O capitalismo pode funcionar dentro de diferentes sistemas políticos [...]. A ideia segundo a qual o capital está sempre acompanhado pela democracia é desmentida a cada dia (LAZZARATO, 2019, p. 54-55).

Então, não se trata de um regime político global que é marcado pela "indeterminação entre democracia e absolutismo", como quer fazer valer Agamben (AGAMBEN, 2004, p. I3): o que temos hoje é o pleno revigoramento do capitalismo em colapso, em detrimento de um capitalismo liberal típico profundamente idealizado. $\mathrm{Na}$ verdade, "o liberalismo não precisa de constituição" (RANCIĖRE, 20I4, p. IO4). A idealização produz uma falsa similitude entre democracia e "normalidade". O paradoxo desconfortável é que o capitalismo global e sua democracia política mobilizam dialeticamente normalidade e anomia no seu conceito de realismo. É a ideologia orientada pela dominação que intenta produzir uma imagem idealizada expressa na contradição entre um capitalismo nocivo e uma democracia pura. A etapa presente do capitalismo mostra que "temos, antes de mais, a brutalidade sem limites, a violência cega do capitalismo atual": a dimensão objetiva da regressividade histórica está no retorno à essência capitalista, ou seja, "nomeadamente o culto do sucesso levado às costas dos outros, a crença nas desigualdades, o desmantelamento das medidas de proteção social, o combate selvagem de todos contra todos numa luta para conquistar uma posição dominante" (BADIOU, 2020, p. 23). É necessário acrescentar à sumarização de Alain Badiou que experimentamos uma poderosa degeneração moral e uma crise da subjetividade, ou seja, a extinção da humanidade do humano é coincidente com o projeto de modernização capitalista: isso significa que a acumulação abstrata de riqueza é proporcional ao desenvolvimento da catástrofe, numa relação permanente de circularidade. Com efeito, a circularidade do colapso é indeterminada e parece não ter limitação. 
A pergunta que precisa ser feita é: pode a democracia interditar o colapso? Walter Benjamin não acreditava nessa solução, tanto que imaginava que as revoluções - ou seja, as autênticas subversões da economia, da política e da subjetividade capitalistas — seriam o "freio de emergência" capaz de impedir a continuidade indefinida do inferno da máquina capitalista. Por conseguinte, a questão decisiva é que o capitalismo tem uma relação permeada pela ambiguidade com a democracia, e que está longe de ser simples. A sentença de Rancière é insuspeita:

Não vivemos em democracias. Tampouco vivemos em campos, como garantem certos autores que nos veem submetidos à lei da exceção do governo biopolítico. Vivemos em Estados de direito oligárquicos, isto é, em Estados em que o poder da oligarquia é limitado pelo duplo reconhecimento da soberania popular e das liberdades individuais. Conhecemos bem as vantagens desse tipo de Estado, assim como seus limites. As eleições são livres. Em essência, asseguram a reprodução, com legendas intercambiáveis, do mesmo pessoal dominante, mas as urnas não são fraudadas e qualquer um pode se certificar disso sem arriscar a vida. A administração não é corrompida, exceto na questão dos contratos públicos, em que ela se confunde com os interesses dos partidos dominantes. As liberdades dos indivíduos são respeitadas, à custa de notáveis exceções em tudo que diga respeito à proteção das fronteiras e à segurança do território. A imprensa é livre: quem quiser fundar um jornal ou uma emissora de televisão com capacidade para atingir o conjunto da população, sem a ajuda das potências financeiras, terá sérias dificuldades, mas não será preso. Os direitos de associação, reunião e manifestação permitem a organização de uma vida democrática, isto é, uma vida política independente da esfera estatal. Permitir é evidentemente uma palavra ambígua. Essas liberdades não são dádivas dos oligarcas. Foram conquistadas pela ação democrática e sua efetividade somente é mantida por meio dessa ação. Os "direitos do homem e do cidadão" são direitos daqueles que os tornam reais (RANCIÈRE, 20I4, p. 94-95, grifos originais).

O que precisamos pensar aqui é a ambiguidade da democracia. É absolutamente verdadeiro dizer que as liberdades democráticas hoje são incrivelmente superiores a tudo que já experimentamos no passado, mas isso não significa que temos uma liberdade verdadeira. O que temos é a reprodução da dominação social mediante o exercício da liberdade negativa contemporânea. Na verdade, podemos dizer que o próprio exercício da liberdade contém um certo tipo de propulsão compulsória. A panaceia da liberdade democrática é desmoralizada pelo próprio capitalismo, que não funciona por decisões democráticas. Como podemos escolher livremente quando somos submetidos a decisões que já foram tomadas sem nossa participação? Robert Kurz lembra que "não é difícil decifrar a assim chamada economia de mercado como o núcleo repressivo da dominação democrática” (KURZ, 2020, p. 25). 
Então, não é somente a presença do "núcleo repressivo" que define nosso acesso à dinâmica da reprodução individual, mas é necessário considerar que a existência de uma democracia oligárquica define o modelo de participação política e o nosso próprio envolvimento social amplo com o mundo capitalista. Yuval Harari diz que "as pessoas só se sentem ligadas a eleições democráticas quando compartilham uma ligação básica com a maioria dos eleitores”, ou seja, as eleições são mais um problema relacionado à formação das crenças do que um modelo racional pelo qual o litígio decisivo é resolvido. Ademais, "elas constituem um método de resolver desacordos entre pessoas que já concordam quanto ao básico” (HARARI, 20I6, p. 255).

É aqui que as coisas ficam mais difíceis, pois a liberdade negativa está colapsada quando se pressupõe que a crença compartilhada - seja por razões étnicas, religiosas, ideológicas, comunitárias etc. — é o que define anteriormente o próprio dissenso democrático e suas formas de resolução. Não há processo substancial transformativo pelo processo da democracia liberal oligárquica. Naquilo que realmente importa, as decisões já estão tomadas. Em vez da instituição de processos radicais de transformação, o que temos é a interdição da mudança. Alain Badiou diz que "a ideologia, quando o inconsciente se forma e se fixa nela, é um processo de repetição” (BADIOU, I979, p. I6). O que a democracia liberal oligárquica faz é produzir a repetição do status quo por meio da participação distorcida do demos.

Como podemos perceber aqui, a despolitização acontece como um fenômeno propriamente ideológico orientado pelos interesses da dominação. Assim, são inúmeros os mecanismos mobilizados — da objetividade inerente à subjetividade atuante - pelos quais a despolitização aparece com o intuito de interditar e sabotar o acontecimento verdadeiramente político. Rancière elabora uma formidável caracterização sobre a dialética do conflito entre a "normalidade" subjacente dos lugares e da ordem dos falantes e as tentativas de resistência e emancipação. Para ele, o sistema dominante mobiliza sua potência como força para que a reprodução da "normalidade" existente siga seu curso sem maiores perturbações, mesmo que isso signifique alterar alguns elementos constituintes do seu próprio metabolismo.

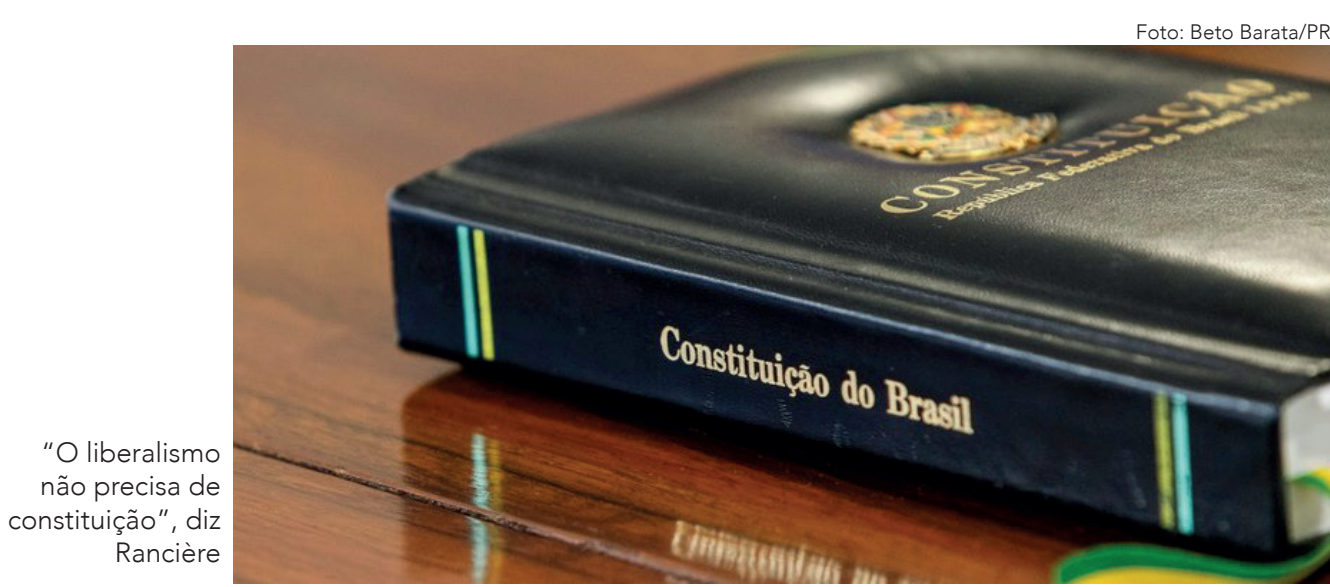


Com efeito, o capitalismo é propriamente inconsistente, ele se adapta e se transforma para que a substância primordial capitalista permaneça. É por isso que as tentativas de mudança mediante alteração do controle político são impotentes. Robert Kurz diz que o fetichismo e o sistema de produção de mercadorias são, de alguma maneira, indiferentes à mudança do controle político. É daí que Kurz critica o "politicismo" estéril da oposição política ao capitalismo, ou seja, "a alegada "vontade de exploração' não é uma dimensão independente, mas uma função sistêmica totalmente dependente, a pura execução de leis e critérios sistêmicos sem sujeito que são assumidos pelos explorados" (KURZ, 2020, p. 27). O puro realismo não pode ser transgredido simplesmente pelo "poder de disposição" da tomada do poder político. A ilusão está justamente na imaginação impotente que pensa "que a extensão dos princípios da democracia política para o 'setor econômico' (e para as instituições burocráticas) superaria todos os males, sofrimentos, crises e catástrofes do capitalismo" (KURZ, 2020, p. 26).

Nesse sentido, a tarefa primordial da despolitização é evitar que o realismo seja modificado. Enquanto a política é a explosão da "normalidade" existente, Rancière vai chamar de "polícia" as tentativas dominantes de impossibilitar o acontecimento verdadeiramente político, ou seja, a transgressão do realismo capitalista: a primeira insiste na partilha do mundo e na instauração de uma forma de vida autêntica, a segunda é a pura legitimação da distribuição desigual dos lugares e da ordem dos falantes. Para Rancière:

A polícia é, na sua essência, a lei, geralmente implícita, que define a parte ou a ausência de parte das "partes". Mas, para definir isso, é preciso antes definir a configuração do sensível na qual se inscrevem umas e outras. A polícia é assim, antes de mais nada, uma ordem dos corpos que define as partilhas entre os modos do fazer, os modos de ser e os modos de dizer, que faz que tais corpos sejam designados por seu nome para tal lugar e tal tarefa; é uma ordem do visível e do dizível que faz com que essa atividade seja visível e outra não o seja, que essa palavra seja entendida como discurso e outra como ruído. É, por exemplo, uma lei de polícia que faz com que tradicionalmente o lugar de trabalho seja um espaço privado não registrado pelos modos do ver e do dizer próprios do que se chama "o espaço público", e onde o ter parte do trabalhador é estritamente definido pela remuneração de seu trabalho. A polícia não é tanto uma "disciplinarização" dos corpos quanto uma regra de seu aparecer, uma configuração das ocupações e das propriedades dos espaços em que essas ocupações são distribuídas (RANCIÈRE, 20I8, p. 42-43, grifos originais).

Estamos diante da discussão da divisão de classes, que não apenas é permanente no capitalismo histórico como faz parte do funcionamento inerente de sua ontologia objetiva. A ordem policial, sustenta Rancière, objetiva reproduzir as hierarquias 
e antagonismos existentes, já que o funcionamento objetivo do capital não atua sozinho no funcionamento do metabolismo social.

Novamente retomamos as controvérsias e impasses da teoria de Habermas. Não se trata de adotar a lógica pautada pela "colonização do mundo da vida" - como se ele fosse destituído de antagonismos e violência —, mas é necessário pensar que existem questões próprias à esfera da "reprodução" que não obedecem às mesmas regras de enquadramento da esfera da "produção". A esse respeito Rahel Jaeggi, em diálogo travado com Nancy Frazer, diz que "práticas econômicas não estão só 'enraizadas' numa forma de vida ética circundante ou possibilitadora; pelo contrário, são parte da própria forma de vida, parte da ordem social e de sua respectiva dinâmica" (FRASER; JAEGGI, 2020, p. 69, grifos originais). É por isso que "nenhum dos domínios 'não econômicos' oferece um ponto de vista inteiramente externo que poderia garantir uma forma absolutamente pura e completamente radical de crítica" (FRASER, 2020, p. 75).

O que temos aqui é a existência de ontologias distintas que estão em curto-circuito no metabolismo social amplo. Podemos dizer que injustiça, violência, dominação etc. não acontecem apenas como uma propriedade interna ao funcionamento do "sistema", mas a própria política reproduz formas brutais de envolvimento pessoal e coletivo. A contradição é despolitizar a economia e, por outro lado, subtrair o potencial violento (e transformativo) da política.

A questão importante aqui a considerar é que há uma parte do corpo social que é pura ausência na ordem simbólica e política do sistema como um todo. Lazzarato chama de "secessão dos possessores" (LAZZARATO, 20I9, p. 50) a ordem que sobrevive pela divisão constitutiva básica. Como a economia não é capaz de resolver tudo, a política aparece como necessária na reprodução social do sistema, sobretudo tentando impedir que as consequências do sistema possam ser mobilizadas na forma da política emancipatória. Nesse sentido, a tarefa fundamental da polícia é manter e reproduzir o sistema de hierarquias e divisões existentes no metabolismo social. A despolitização é o objeto supremo da polícia. Ela tem a capacidade de evitar que o dano produzido pelo sistema possa ser transformado em reclamação autêntica coletiva, ou seja, em política em estado puro.

Mas o que seria a política? A ideia da política é pensada "para uma atividade bem determinada e antagônica à polícia", ou seja, "aquela atividade que rompe com a configuração sensível em que as 'partes' ou sua ausência são definidas com base em um pressuposto que, por definição, não tem lugar: o de uma parte dos que não têm parte" (RANCIÈRE, 20I8, p. 43, grifos originais). A nomeação da populaça ou do proletariado hoje precisa ser pensada na configuração objetivo-subjetiva de uma localização social e simbólica rigorosa, considerando-se que esse grupo de pessoas está reduzido na ordem social subjacente a "uma parte dos que não têm parte". O que a antipolítica faz aqui é traduzir a insatisfação e ressentimento daqueles que não têm parte numa forma política regressiva: fascismo é o termo preciso capaz de capturar todo o circuito dos afetos da reação da antipolítica à própria democracia. 


\section{A OBSCENIDADE DO FASCISMO DEMOCRÁTICO}

Michela Murgia lembra que o fascismo é corporificado na figura do chefe, que, na incapacidade de apresentar uma solução racional e lúcida para o problema da divisão constitutiva básica, precisa criar um inimigo em que possa ser depositada toda a culpa pelo caos e desordem existentes. Não há fascismo sem que exista uma ordem de insatisfações e frustrações que, a um só tempo, são capturadas pela fascistização e atuam mobilizando os afetos das pessoas comuns. É justamente a capacidade de deslocamento da causa que possibilita ao discurso fascista ter força para penetração social e inculcação ideológica na subjetividade das pessoas. Não podemos esquecer que todo fascismo é populista ${ }^{2}$, mas nem todo populismo é fascista.

Assim, o fascismo atua como um discurso político de combate à democracia, tentando deslegitimá-la, e se localizando ao lado daqueles que foram rejeitados pelo sistema democrático. Adorno apresenta o fascismo como a corporificação do "novo radicalismo de direita" (ADORNO, 2020). Todo fascismo atua diretamente na restauração dissimulada do realismo capitalista por meio de uma radicalidade política importante. O fascismo hoje oferece a revolução como horizonte normativo, pois seu discurso antissistema e antiordem atua como mobilizador do ressentimento e do ódio despolitizado. Ele precisa construir sempre uma oposição sistemática ao comunismo, aparecendo simbolicamente em relação a este como uma alternativa de sinal trocado. É, de fato, uma ambiguidade do fascismo a exponenciação de sua posição antidemocrática. A ideologia fascista sabe que não pode levar a sério demais sua agitação virulenta antidemocrática. Temos aqui uma similitude notável com o populismo:

O populismo de hoje reclama de como suas mãos estão atadas pelo "Estado profundo" e pelo establishment financeiro. Sua mensagem é que "se ao menos não estivéssemos de mãos atadas, seríamos capazes de acabar com nossos inimigos de uma vez por todas". No entanto, em contraste com

2 É fundamental explorar essa equação teórica, pois a noção de populismo é bastante controversa e pouco consensual. A noção adotada aqui incorpora aspectos derivados das interpretações de Slavoj Žižek e Ernesto Laclau. Primeiro, Žižek diz que "a ideologia fascista 'manipula' o desejo popular autêntico de verdadeira comunidade e de solidariedade social contra a competição feroz e contra a exploração; sem dúvida 'deforma' a expressão desse desejo com o fim de legitimar a perpetuação das relações da dominação e exploração sociais. Seja como for, a fim de ser capaz de levar a bom termo o seu objetivo, nem por isso depara menos com a obrigação de incorporar uma autêntica aspiração popular" (ŽlŽEK, 2006, p. 27). Depois, Laclau diz que "o fascismo, longe de constituir a expressão ideológica típica dos setores mais conservadores e reacionários das classes dominantes, foi, ao contrário, uma das formas possíveis de articulação das interpelações popular-democráticas ao discurso político" (LACLAU, 1979, p. 117). Nesse sentido, todo fascismo é populista, no preciso sentido de que sua mobilização ideológica precisa ter incorporado algum tipo de componente popular autêntico na sua ideologia política. Essa posição tem similitude com a análise de Laclau, quando ele insiste que o fascismo articula aspirações populares no discurso político. Por outro lado, é possível deduzir que nem todo populismo é fascista, já que como o populismo é uma forma de interpelação das demandas populares, o conteúdo - e inclusive a forma - da interpelação não é necessariamente orientado ou mobilizado de maneira distorcida como faz o fascismo. O populismo acaba sendo uma resposta à crise de legitimação do poder político tradicional. É nesse sentido que o fascismo funciona — e se reproduz — graças à colonização da revolta popular. O problema decisivo é quando o populismo aparece como a coluna do meio - populismo de direita e populismo de esquerda - em que o conflito político aparece. Na verdade, o verdadeiro conflito ou antagonismo decisivo é o próprio capitalismo e seus semblantes. 
o velho populismo autoritário (como o fascismo), que está disposto a abolir a democracia formal-representativa e realmente tomar o poder para impor uma nova ordem, o populismo de hoje não tem uma visão coerente de alguma nova ordem. O conteúdo positivo de sua ideologia e de sua política é uma bricolagem inconsistente de medidas para subornar "os nossos" pobres, reduzir os impostos para os ricos, concentrar o ódio em figuras como imigrantes, minorias, a nossa "elite corrupta que está fazendo com que nossos postos de emprego saiam do país", e por aí vai... É por isso que os populistas de hoje realmente não querem se livrar da democracia representativa estabelecida e assumir totalmente o poder: livre dos 'grilhões' da ordem liberal contra aos quais finge lutar, a nova direita teria realmente de tomar alguma ação real, e isso evidenciaria a vacuidade de seu programa. Os populistas de hoje só podem funcionar na chave do adiamento indefinido de seus objetivos, pois eles só podem funcionar como oposição ao "Estado profundo" do establishment liberal: "A nova direita não busca, pelo menos não neste momento, estabelecer um valor supremo - por exemplo, a nação ou o líder — que expressaria plenamente a vontade do povo, e assim permitir e talvez até exigir a abolição dos mecanismos de representação" (ŽIŽEK, 2021, grifos originais).

No limite, a democracia é tratada como uma farsa, uma manipulação produzida por uma pequena elite de privilegiados e conspiradores que atuam diretamente contra os interesses da nação, os valores tradicionais arraigados etc. Na incapacidade de abandonar a democracia e tomar realmente o poder, a dissimulação está na construção ideológica de um ponto falso de crítica e atenção que precisa ser compartilhado. A verdade é que o esgotamento da democracia é utilizado oportunamente pelo fascismo para que ele possa se apresentar como ausente da decomposição democrática em curso. Isso faz com que o ponto falso elaborado pelo fascismo distorça a localização dos verdadeiros problemas. É assim que a posição fascista aparece como uma posição outsider e capaz de representar o desejo popular contra o sistema dominante. Vladimir Safatle lembra que o fascismo é "a colonização do desejo anti-institucional pela própria ordem” (SAFATLE, 20I8, p. I6).

Do ponto de vista da hegemonia, o fascismo tem a potente capacidade de "incorporar uma autêntica aspiração popular" na sua reclamação política, mesmo considerando-se que "a ideologia fascista 'manipula' o desejo popular autêntico de verdadeira comunidade e de solidariedade social contra a competição feroz e contra a exploração" (ŽIŽEK, 2006, p. 27). Não é difícil imaginar a capacidade mobilizadora do fascismo - pois apresenta como política a universalidade ideológica do componente popular autêntico da hegemonia dominante - contra o sistema democrático. É assim que o fascismo mobiliza a divisão constitutiva a seu favor, dando corpo ao ressentimento, frustração e ódio despolitizado daqueles que não têm parte na criação do inimigo comum, que é apenas um ponto falso ideologicamente produzido: 
Ninguém se torna fascista sem um inimigo, pois, para o fascismo se impor, ele deve se contrapor. Dirão que isso não é diferente na democracia, porque no final das contas, sempre que as pessoas têm de votar, um vota contra o outro. Não é exatamente assim, porque os democratas não conseguem renunciar à ideia de legitimar as diferenças de pensamento, e continuam a ser inexplicavelmente generosos com aqueles que apresentam dissensos. Eles não chamam seus antagonistas políticos de inimigos, mas de adversários, uma figura inútil e incômoda que, por mais que possa ter ideias diferentes, permanece, de toda forma, na dialética do reconhecimento (MURGIA, 2019, p. 45, grifos originais).

A ambiguidade da democracia é que ela permite a circulação de formas de pensamento e linguagem regressivas, pois se a democracia é o regime político do dissenso, parece tolerável a suas premissas que os fascistas possam exercer seus direitos políticos democraticamente. Nesse caso, a atuação da antipolítica funciona como um mecanismo de enquadramento que impossibilita a existência plena da democracia, já que ela é reativa e contrapõe à própria democratização da sociedade formas de recuo e interdição. Partindo da ontologia dos afetos, o fascismo mobiliza os afetos negativos — medo, ressentimento, frustração, raiva, ódio etc. — na constituição de sua hegemonia ideológica.

A democracia é o regime ideológico que intenta encobrir a cisão constitutiva que impossibilita que as partes que não têm parte no corpo social possam ser reconhecidas no todo: é assim que os democratas vão insistir na ideia de que, mesmo se tratando de um regime político falho e dotado de incompletude, ainda assim é o melhor sistema político possível. Como precisamos seguir insistindo, o paradoxo é que o "desigualitarismo" objetivo produzido no e pelo capitalismo não é corrigido pela democracia. O fascismo se utiliza dessa falha estrutural para impor toda responsabilidade à democracia, deslocando a causa autêntica da ontologia de funcionamento do capitalismo para o regime democrático que controlaria a democracia - ou, pelo menos, para a existência fantasmática de uma elite manipuladora e corrupta que a controla - , ou seja, o fascismo aproveita a permissividade democrática do dissenso para aparecer como alternativa ideológica hegemônica:

Essa propensão dos democratas a legitimar tudo é estúpida, sem dúvida, mas muito útil para o fascismo: ao se apresentar para as eleições com o bom senso de evitar dizer explicitamente "Somos fascistas", há boas chances de que os bobocas democratas deixem a pessoa se candidatar, ganhar votos e até governar, convencidos de que seja simplesmente um adversário com ideias um pouco diferentes. Como em Troia, não adianta tomar nada de assalto: basta construir um cavalo de madeira e serão as próprias instituições democráticas a lhe abrirem as portas. Apresentar-se como adversário é um ótimo cavalo de Troia (MURGIA, 2019, p. 46-47). 
Não é justamente isso que podemos aprender com as eleições de Trump e Bolsonaro? A baixa fricção com que a comicidade caricatural dos chefes fascistas é apresentada faz dela potencialmente frágil, pouco danosa, até mesmo engraçada, despertando alguma curiosidade na consciência amena. Vladimir Safatle insiste que a colonização do desejo ganha corpo em "uma liderança que parece estar acima da lei, que parece poder falar o que quiser sem culpa, expor seus piores sentimentos sem preocupação com seus efeitos, demonstrar seu desejo mais baixo de violência como expressão de uma liberdade conquistada" (SAFATLE, 20I8, p. I6-I7).

Nesse sentido, é necessário que os líderes fascistas "pareçam cômicos, sejam uma mistura de militar com palhaço de circo", ou seja, "só assim, através dessa ironização, tais proposições poderão circular com fricção baixa” (SAFATLE, 20I8, p. I6-I7). O componente popular autêntico inerente ao fascismo produz capilaridade e dá concretude a sua reprodução social. É por isso que fascismo consegue ter circulação no coração das sociedades democráticas. Na prática, o fascismo é extremamente violento e tem pouca relação orgânica com a soberania popular. Com efeito, os fascistas constituem suas próprias bolhas políticas, falando e atuando para elas e em torno delas.

Na verdade, como há a estetização da política sob o fascismo, o que acontece é a substituição mais que perfeita do povo pela base fascista mobilizada. Assim, diferentemente da democracia, que busca encobrir a falha existente na realidade, "o fascismo é de fato tanto menos 'ideológico', na medida em que proclama de modo imediato o princípio da dominação que no mais fica oculto” (ADORNO, 2008, p. IO4). Aqui temos uma ambiguidade importante, pois o conceito de verdade não existe no fascismo. Como apresenta suas posições como legítimas, desestabilizando todo critério racional mínimo compartilhado em que o dissenso democrático possa ter resolução, a fronteira entre verdade e mentira é eliminada. A verdade assume uma disposição ideológica de força. Michela Murgia elabora o paradoxo da antipolítica fascista nesse quesito:

As pessoas comuns, que na democracia são obrigadas a se interessar, a se informar e a decidir, com o fascismo viverão em paz, tomarão conta da própria vida e de bom grado delegarão todo o resto ao chefe. Por isso, fazê-los entender os detalhes de tudo o que está acontecendo é perda de tempo: é suficiente dizer o necessário para que se permitam confiar em quem está decidindo. Também não é preciso que tudo o que está sendo transmitido seja verdadeiro, porque a verdade em si não existe: é um dado político, não um dado da realidade, e, portanto, quem governa a política sempre governa também a verdade (MURGIA, 20I9, p. 40-4I).

Uma questão importante é que a própria reação democrática se equivoca ao deslegitimar a existência ideológica (e prática) do fascismo propriamente dito. À ordem democrática, o fascismo aparece como populismo de direita ou extremismo, mas jamais como fascismo. A verdade do fascismo é exitosa quando ele é traduzido como mentira política. O fascismo é tão mais potente ideologicamente quanto menos ele é 
chamado pelo próprio nome; podemos dizer que sua imbricação com a democracia impede que ele apareça em sua forma pura. O erro primordial dos democratas é que "no fundo desejam, com todas as forças, acreditar que o fascismo não existe, que é um fenômeno histórico superado" (MURGIA, 20I9, p. 47).

Entretanto, o que podemos nos perguntar agora é: e se o fascismo não tiver forma pura? É possível que estejamos diante de uma experiência de fascismo que pode aparecer somente na democracia? Parafraseando Agamben, o fascismo hoje aparece como uma certa indeterminação entre a pura repressão e a própria democracia. O impasse decisivo é quando o fascismo em funcionamento é refletido como um "ainda não". O erro da crítica é tomar o fascismo como um objeto puro, quando na verdade sua obscenidade inerente oblitera seu aparecimento plenamente transparente. A verdadeira barreira ideológica é quando temos dificuldade - ou estaríamos diante de uma impossibilidade? - em dizer que o fascismo é fascismo.

Temos de lembrar aqui Adorno, que já havia antecipado de maneira extraordinária o impasse ideológico da democracia com uma sentença aterradora: "Eu considero a sobrevivência do nacional-socialismo dentro da democracia potencialmente mais ameaçadora do que a sobrevivência das tendências fascistas contra a democracia." (ADORNO apud GORDON, 202I) Não é isso que quer dizer Michela Murgia quando assinala que o sistema democrático incorpora o fascismo ao nomeá-lo como adversário político? A ausência de uma fronteira política inteligível, capaz de definir o espaço comum compartilhado para que o dissenso possa ser estabelecido, é o que permite que o fascismo atue politicamente e seja considerado como uma ideologia política legítima. A crise inerente à democracia (e a suas elites políticas), combinada com a impossibilidade de o "sistema" produzir alguma solução à lacuna subjacente do "desigualitarismo", é o que explica o ressurgimento do "novo radicalismo de direita": Na verdade, a liberdade democrática se revela como um vazio tão evasivo quanto voraz. Assim como Saturno, o totalitarismo monetário de mercado devora seus próprios filhos. A lógica interna de dominação do sistema democrático de mercado expulsa repressivamente e, em seguida, produz como reação, em vez de uma nova crítica emancipatória, um eco assassino de si mesma. A democracia e o radicalismo de direita se correspondem como gêmeos siameses, conectados internamente pelo sistema circulatório do processo de valorização abstrato e suas coerções surdas. Toda democracia produz como reação imanente ao fim do processo de modernização, com regularidade lógica, o novo radicalismo de direita em qualquer de suas variações. A máscara hipócrita da liberalidade propõe um pacto, mas é o punho de Fausto da própria essência fetichista que golpeia em delírio cego (KURZ, 2020, p. 34, grifos originais).

Podemos repetir aqui que a dominação democrática produz "um eco assassino de si mesma", como resultado de um processo em que "expulsa repressivamente" e "produz como reação" seu próprio calvário, numa circularidade explosiva. O fascismo 
é um processo de alienação imediata à causa, pois se trata de uma distorção fundamental do objeto do dano. Talvez seja por essa razão que fascismo não seja operado como fascismo. No entanto, a dificuldade ideológica de nomeação da coisa em si do fascismo tem relação direta com o fracasso da democracia. O fascismo é um tipo de ultraliberalismo autoritário: o desejo de exponenciação dos interesses econômicos capitalistas com uma forma política desprovida do dissenso democrático. Nesse caso, a coisa em si do fascismo está latente e não é facilmente descoberta.

A assimilação do fascismo pela democracia oblitera ainda mais a distinção entre o que é tolerável como mero dissenso pelo sistema democrático e o que deveria ser reprimido ideologicamente como propriamente repugnante. A questão fundamental é que o "desigualitarismo" repugnante é uma característica incorrigível do capitalismo histórico. O que pode fazer a democracia? Na verdade, a democracia atua como um tipo de regime político que funciona normalizando tudo aquilo que é parte do metabolismo do sistema - ou seja, as formas mais significativas de exploração, rejeição, humilhação etc. - , ao mesmo tempo que expurga, através de fronteiras físicas e simbólicas muito bem definidas, tudo o que está além dos seus limites tácitos.

Donatella Di Cesare classifica de "democracia imunitária" uma forma política que imuniza alguns poucos contra o contágio pela comunidade e suas consequências desumanizadoras. Para ela, "é tudo o que o cidadão exige da democracia: não me toque” (DI CESARE, 2020, p. 46, grifos originais). Essa posição é derivada da concepção moderna de liberdade negativa, cujo núcleo decisivo é a alienação da liberdade em troca da garantia da segurança pelo Leviatã, como elabora Hobbes. É curioso pensar que, na suspensão do mundo operada pela pandemia global, há um deslocamento decisivo dos contornos da fronteira estabelecida pela "democracia imunitária”: "A nova fronteira é a máscara facial. O ar que respiras deve ser só teu. A nova fronteira é a tua epiderme. A nova Lampedusa é a tua pele." (PRECIADO, 2020) Temos aqui uma concepção de poder político restrita à garantia da imunidade de seus cidadãos contra espoliações ou invasões externas.

Assim, como a democracia está sempre tensionada pelo curto-circuito entre aqueles que não têm parte no corpo social e a plena representação - não apenas política, mas econômica, ideológica, cultural etc. - , todas as formas de exclusão que produzem a populaça como disposição para a revolta precisam ser manipuladas. A causa autêntica - o capitalismo global e seu sistema democrático de governos supérfluos — não pode aparecer ideologicamente, mas o inimigo externo comum precisa ocupar o espaço da reclamação contra o dano. A distorção não elimina a realidade subjacente. Ela aparece em substituição à realidade objetiva. É assim que a imunização aparece como uma característica intrínseca do funcionamento do próprio capitalismo. Antes mesmo da pandemia global, já estávamos diante de um sistema de imunidade social vigoroso:

A condição de imunidade reservada a alguns, os protegidos, os preservados, os garantidos, é negada a outros, os expostos, os rejeitados, os abandonados. 
Esperam-se cuidados, assistências e direitos para todos. Mas o "todos" é uma esfera cada vez mais fechada: tem fronteiras, exclui, abandona sobras e restos. A inclusão é uma miragem ostentada, a igualdade é uma palavra vazia que agora soa como uma afronta. O abismo aumenta, o fosso se aprofunda. Não é mais apenas o apartheid dos pobres. A discriminação é precisamente a imunidade, que escava o sulco da separação, já presente no interior das sociedades ocidentais e muito mais intensa do lado de fora, na hinterlândia sem fim da miséria, nas periferias planetárias do desconforto e da desolação. Ali onde sobrevivem os perdedores da globalização não chega o sistema de garantias e de segurança. Internados nos campos, estacionados nos vazios urbanos, descartados e acumulados como lixo, esperam pacientemente uma reciclagem eventual. Mas a sociedade que usa e descarta não sabe o que fazer com seus excedentes. As escórias poluem. É melhor, portanto, manter uma distância segura das pessoas contaminadas, contamináveis, fontes de doenças, causas de contágio (DI CESARE, 2020, p. 47-48, grifos originais).

No capitalismo, o que temos é um tipo de democracia imunitária que reserva não apenas acesso limitado ao capitalismo como à própria democracia. Os pobres não têm lugar, são rejeitados como fracassados por não conseguirem ser consumidores, têm sua participação política desqualificada. No limite, em função da existência do parlamentarismo, são reduzidos à condição de apenas eleitores. Essa situação de desqualificação de sua existência política transforma a populaça no objeto sublime do contágio. A secessão produzida pela ideologia política dominante transforma toda comunidade num embaraçoso hiato que se desenvolve na forma do apartheid social, cujo objetivo é evitar o contágio pelas classes perigosas - e o envolvimento político decisivo delas. As classes dominantes cada vez mais precisam se valer da violência para seguir mantendo o sistema de dominação social atual.

Maurizio Lazzarato diz que "o controle e a regulação das populações já não se fazem pela integração e pela biopolítica, mas pelo apartheid social", pois a "máquina de guerra capitalista" significa o funcionamento do "projeto de secessão política dos ricos" (LAZZARATO, 20I9, p. 52-53, grifos originais). A lógica da imunidade que está inscrita na secessão é antagônica ao primado do contágio que a ideia de comunidade pressupõe. O que a imunização — como aparência apartheid social — inviabiliza é qualquer possibilidade de comunidade, já que esta significa envolvimento, partilha, solidariedade etc. É o "sistema sem sujeito" que produz a indiferença, desapego e apatia, como características típicas da radicalização do Antropoceno sob o capitalismo. É por isso que podemos dizer que "onde a imunidade prevalece não há mais comunidade" (DI CESARE, 2020, p. 5I).

Nesse sentido, a populaça é o verdadeiro grupo social de risco, que precisa ser evitado e combatido: a função das classes da dominação - e por isso dominantes - é evitar seu próprio empobrecimento e proletarização, ao mesmo tempo que precisam 


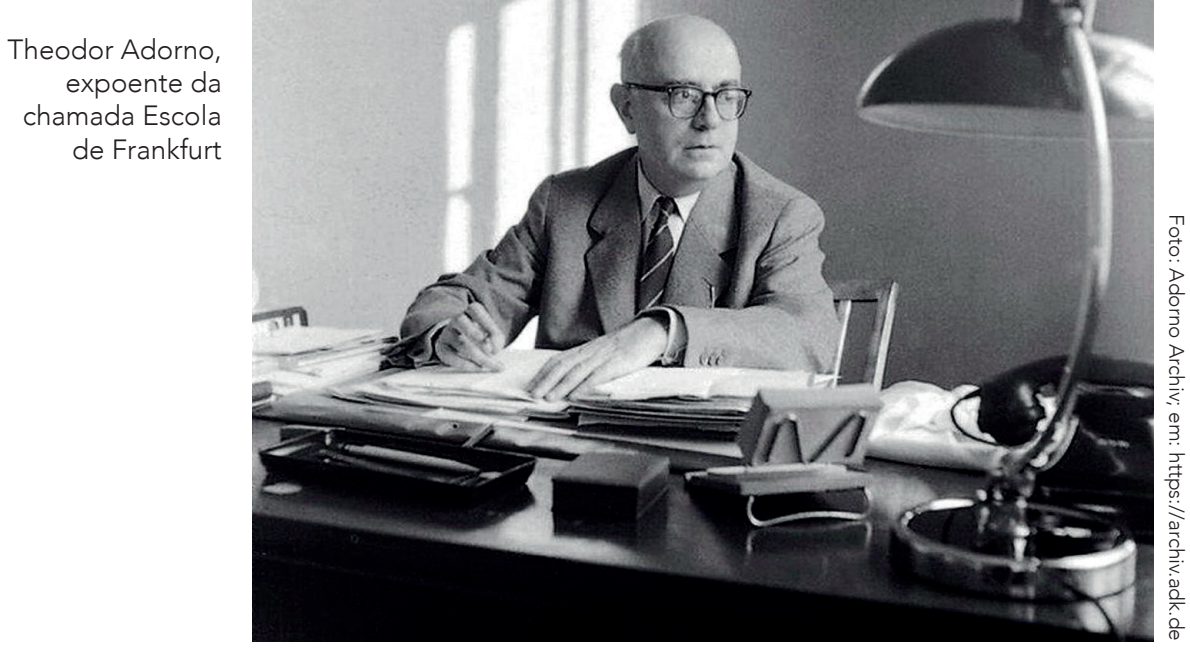

combater ideologicamente qualquer tipo de reação política na forma de revolta contra o sistema da dominação. O paradoxo é que o sistema democrático aparece como alternativa impotente de resolução do conflito estrutural básico. Ademais, a sensação de que a democracia é um jogo oligárquico desloca o humor político para posições que atuam como alternativas antissistêmicas:

O chamado sistema majoritário elimina os partidos extremos e dá aos "partidos de governo" o meio de governar em alternâncias; desse modo, permite à maioria — isto é, à minoria mais forte — governar sem oposição durante cinco anos e tomar, para a garantia da estabilidade, todas as medidas que, para o bem comum, o imprevisto das circunstâncias e a previsão de longo prazo exigem. De um lado, essa alternância satisfaz o gosto democrático pela mudança. De outro, como os membros desses partidos de governo estudaram a mesma coisa nas mesmas escolas de onde saem também os especialistas em gestão da coisa comum, tendem a adotar as mesmas soluções que fazem a ciência dos especialistas primar sobre as paixões da multidão. Cria-se assim uma cultura do consenso que repudia os conflitos antigos, habitua a objetivar sem paixão os problemas de curto e longo prazo que as sociedades encontram, a pedir soluções aos especialistas e discuti-las com os representantes qualificados dos grandes interesses sociais. Infelizmente, todas as boas coisas têm sem anverso: a multidão desobrigada da preocupação de governar fica entregue a suas paixões privadas e egoístas. Ou os indivíduos que a compõem se desinteressam do bem público e se abstêm de votar nas eleições ou as abordam unicamente do ponto de vista de seus interesses e caprichos de consumidores. Em nome de seus interesses corporativistas imediatos, opõem greves e manifestações à medida que visam garantir o futuro dos sistemas de aposentadoria; em nome de seus caprichos individuais, escolhem nas eleições o candidato que mais lhes agrada, da mesma maneira que escolhem entre os inúmeros tipos de pão que as padarias descoladas oferecem. O resultado é que os "candidatos de protesto" ganham mais votos do que os "candidatos de governo" (RANCIÈRE, 2OI4, p. 95-96). 
É assim que o fascismo emerge por dentro do sistema democrático, ou seja, sua localização política aparente como alternativa de protesto faz com que ele passe paulatinamente a ter penetração e capilaridade social na populaça. Como a política tradicional mostra-se incapaz de representar todos e a igualdade é apenas um simulacro ideológico eleitoral, o fascismo aparece como um tipo de substituto político capaz de acabar com os privilégios oligárquicos das castas parasitárias que atuam por dentro do sistema democrático. Não se trata realmente de acabar com a democracia - como demonstrado convincentemente por Adorno e Kurz —, o objetivo é distorcê-la, esvaziando seu conteúdo explosivo. É a própria ontologia inconsistente do capitalismo que faz com que ele se adapte às variações da política, isto é, "o capitalismo pode funcionar dentro de diferentes sistemas políticos" (LAZZARATO, 20I9, p. 55).

Quando a lógica consensual é esgotada - a democracia liberal pura -, o capitalismo pode se valer de formas diretamente autoritárias de domínio político. O cansaço da decisão e da participação alienada esgota o desejo de democracia pela maioria silenciada e dominada. $\mathrm{O}$ autoritarismo político imediato não é uma necessidade imperativa da dominação social capitalista. Na verdade, a dominação social sem sujeito — nos termos de Marx e Kurz - é a forma típica pela qual o capital exerce seu poder. O "novo autoritarismo de direita" é uma solução regressiva perante a crise da democracia em dar conta da lacuna ontológica.

Nesse contexto podemos analisar criticamente o papel ideológico exercido pelo politicamente correto. Na verdade, trata-se de uma higienização da linguagem e do comportamento moral que, em grande medida, estabelece um tipo de falsa oposição entre uma elite culta e intelectualizada e a massa em estado puro. A ridicularização dos costumes populares e o policiamento moral do comportamento do outro funciona apenas como a reprodução habitual das hierarquias subjacentes ao capitalismo. $\mathrm{O}$ resultado inesperado é o fortalecimento das fronteiras de classe: preconceito, elitismo e distanciamento social. A solução apresentada pelo fascismo ao ressentimento produzido pelo sistema democrático é uma política antissistema poderosa. A erosão ideológica da política democrática é objetivada com a eficaz interiorização política do populismo fascista. Michela Murgia elabora uma brilhante simulação da reação do fascismo ao politicamente correto:

O politicamente correto matou a fresca espontaneidade deste país, obrigando-nos a fingir que não vemos o que realmente temos à frente. Para sermos gentis, acabamos nos tornando mentirosos ao aceitar usar expressões que servem para parecermos mais elegantes do que as pessoas sentadas no balcão da padaria. A política fascista, no entanto, não precisa de falsos intelectualismos para se sentir superior a quem representa: nós não somos superiores ao povo, nós somos o povo e falamos como o povo. Se existe um lugar no mundo onde todos têm de nos entender, esse lugar é exatamente o balcão da padaria, onde aliás há muito mais gente do que na universidade. A linguagem fascista, pensando bem, é mais democrática do que a politicamente correta, pois não deixa 


\title{
Em substituição à soberania popular inexistente e distante de proporcionar à populaça o acesso à participação, o fascismo impulsiona a liberdade de tudo dizer. Não precisamos mais de uma circulação política do dissenso, nem de uma verdade definida exteriormente. A verdade está em cada um
}

\begin{abstract}
ninguém se sentir inferior, mesmo que, obviamente, muitos dos democratas se sintam superiores. Não tenham raiva deles, pelo contrário, sintam-se gratos, ao menos num primeiro momento. Toda vez que algum deles procurar reivindicar o uso de expressões refinadas ou diplomáticas, chamando-nos talvez de ignorantes ou grosseiros, estará nos oferecendo a possibilidade de mostrar ao povo que os democratas se preocupam muito mais em colocar em suas bocas o subjuntivo do que um pedaço de pão. Deixem que o façam: só assim os radicais chiques aprenderão por conta própria que não existe uma única sociedade no mundo na qual os povos prefiram o subjuntivo (MURGIA, 20I9, p. 78-80).
\end{abstract}

Podemos perceber aqui toda a dimensão do populista fascista, quando organiza sua atuação justamente na falha estrutural do sistema dominante. O fascismo fala para "as pessoas sentadas no balcão da padaria", dando-lhes explicações palatáveis para o "desigualitarismo" - no sentido de que sejam adaptáveis à consciência média das pessoas comuns, pois se trata de buscar sua adesão alienada à causa distorcida - e traduzindo suas frustrações e ressentimentos na forma de um ódio despolitizado contra a democracia. Ou seja, é uma forma de interpelação popular regressiva.

Ter isso em conta agora significa considerar que "o fascismo nunca foi realmente derrotado", como nos faz lembrar Peter Gordon (202I), e que ainda vivemos sob as sombras do espectro do fascismo autoritário do século XX. Na verdade, Adorno diz que "os pressupostos dos movimentos fascistas, apesar de seu colapso, ainda perduram socialmente, mesmo se não perduram de forma imediatamente política" (ADORNO, 2020, p. 45). O grande problema é a permanência do fascismo - como ideologia - , mesmo quando experimentamos uma época em que o fascismo parece não ter condições objetivas de aparecer.

Com efeito, o que temos hoje é um tipo de fascismo diferente, que não atua contra a democracia, mas funciona dentro dela. A regressão fascista hoje esvazia o sentido da política, pois a transformou em mera propaganda ideológica. A democracia que o fascismo oblitera é apenas uma imagem distante de uma democracia que pudesse ser 
autêntica. Ademais, o fascismo é uma resposta ideológica à incapacidade da democracia em garantir a plena soberania popular, ou, como sentencia Adorno, "poderíamos caracterizar os movimentos fascistas como as feridas, as cicatrizes de uma democracia que até hoje ainda não faz justiça a seu próprio conceito" (ADORNO, 2020, p. 5I). Há aqui um desencontro explosivo entre o conteúdo latente da democracia e seu conteúdo manifesto, ou seja, temos uma democracia que é incapaz de garantir igualdade, liberdade e felicidade - que é a conjunção do seu conteúdo econômico objetivo — quando limitada à sua dimensão meramente formal.

Em substituição à soberania popular inexistente e distante de proporcionar à populaça o acesso à participação, o fascismo impulsiona a liberdade de tudo dizer. Não precisamos mais de uma circulação política do dissenso, nem de uma verdade definida exteriormente. A verdade está em cada um, que pode tudo dizer. Todos podem falar. A tarefa política do fascismo é permitir que todos possam falar livremente sobre qualquer assunto, mesmo que não tenham especialidade nele. Na verdade, os especialistas são representantes imediatos do sistema oligárquico dominante. Para o fascismo, “a verdade em si não existe: é um dado político, não um dado de realidade, e, portanto, quem governa a política sempre governa também a verdade" (MURGIA, 20I9, p. 4I).

Não é difícil imaginar que quando não temos mais um parâmetro objetivo seguro para que a verdade seja definida - amparado na realidade material e simbólica existente -, a mentira como forma ideológica aparece como solução normalizada para as decisões políticas e ideológicas fundamentais. $\mathrm{O}$ resultado desastroso permite que a opinião tenha maior crédito do que a ciência e a verdade. É assim que toda opinião pessoal alcança o estatuto de validação universal e, como tal, tem imunidade contra qualquer forma de contestação e refutação. Não temos assim nenhum mecanismo consensual de resolução dos conflitos. A lição que podemos tirar daqui é que todos os instrumentos utilizados de maneira fascista — os meios não são puros e imunes — são absolutamente úteis à reprodução ampliada do fascismo.

Destarte, a manipulação fascista objetiva desqualificar a democracia, enquanto autoriza a mentira e a distorção como formas de revolta ante o monopólio democrático da produção da verdade. Adorno apresenta uma equação importante sobre a validação da mentira fascista:

O que está por trás do antiamericanismo, isso é difícil dizer. Provavelmente ele é em parte a ligação com algo que se sente concretamente, a saber, com o fato de que, sob a democracia formal, o sistema de blocos faz as pessoas se crerem - e não somente se crerem — privadas da plena liberdade de decisão política. Talvez eu possa dizer isso en passant; eu queria apontar aqui que de modo algum todos os elementos dessa ideologia são simplesmente falsos, mas que também o verdadeiro entra a serviço de uma ideologia não verdadeira e que o truque essencial para resistir a isso consiste em denunciar o abuso da verdade pela inverdade. A técnica mais importante pela qual uma verdade é colocada a serviço da inverdade é a de retirar as observações verdadeiras ou corretas de seu contexto, isolá-las, 
A mentira funciona como uma poderosa

ferramenta ideológica de repetição, mas

não só, ela produz um novo conceito

de "verdade" sem universalidade

efetiva - como Adorno insiste, uma

verdade particular está submetida à

mentira do fascismo - , embora tenha

sentido mobilizador na constituição

da identidade e do universo de delírio

pessoal experimentado pelo indivíduo

desamparado na massa excitada

como por exemplo quando dizem: "Antes de ele ter feito aquela guerra idiota, com o Hitler estava bastante bom para a gente", sem que se veja que toda essa conjuntura entre 1933 e 1939 só foi possível por meio da frenética economia de guerra, da preparação para a guerra" (ADORNO, 2020, p. 65).

Ou seja, a verdade, que evidentemente possui uma dimensão emancipatória - quando participa diretamente de processos amplos de subjetivação e libertação coletivas -, aqui é esvaziada completamente de sentido, manipulada, até que desapareça em absoluto. O que o fascismo faz é manter um permanente funcionamento da propaganda, cuja função é a agitação constante de sua base social. Ela precisa ser mantida em elevado nível de excitação: política, ideológica e simbólica.

Em tempos de tecnologização das formas de comunicação, em razão da amplitude da internet, o trabalho duro da democracia liberal - que na sua "normalidade" exigiria a passagem por um longo e conturbado processo de convencimento - é substituído por uma (pseudo)democratização da opinião, o que, na verdade, significa a desqualificação da verdade como possibilidade. O que temos é a erosão do sentido de que uma verdade tenha validação universal. É assim que a participação política — que pressupõe o dissenso e a condição de ser minoria em determinados assuntos públicos — é substituída pelo compartilhamento nas redes sociais. Aqui, a disputa de posições e o envolvimento político são dispensáveis e, quase sempre, supérfluos. Senão vejamos:

Diferentemente da democracia, o escopo da comunicação no fascismo não é se fazer entender, mas se fazer repetir, e por isso nós temos sorte em sermos fascistas em tempos de internet: fazemos menos esforço, porque os instrumentos nasceram exatamente para isso. O que mais é o compartilhamento, no fundo, senão uma infinita repetição de uma única mensagem proveniente de uma 
única fonte? Usando poucas palavras de ordem e slogans simples, que podem ser transformados em hashtags, acontecerá que todo o trabalho antes realizado por um ministério específico será feito e impulsionado pelos próprios cidadãos, com a vantagem de que eles acreditarão ser a origem da mensagem, e não seu destinatário (MURGIA, 20I9, p. 4I-42).

A posição de Michela Murgia torna contemporâneo o entendimento elaborado por Adorno, isto é, a intencionalidade da "propaganda serve menos para a disseminação de uma ideologia, que é demasiado pobre, como lhes disse, e mais para tornar as massas engajadas". Na verdade, acrescenta Adorno de maneira antecipatória ao que temos hoje, "a propaganda é, portanto, sobretudo uma técnica de psicologia das massas" (ADORNO, 2020, p. 67). O engajamento ativo é uma das formas poderosas de mobilização fascista da subjetividade pessoal e de construção da colaboração.

A lógica da excitação é interna à economia libidinal que liga as pessoas singulares ao chefe fascista. É assim que a mentira funciona como uma poderosa ferramenta ideológica de repetição, mas não só, ela produz um novo conceito de "verdade" sem universalidade efetiva - como Adorno insiste, uma verdade particular está submetida à mentira do fascismo - , embora tenha sentido mobilizador na constituição da identidade e do universo de delírio pessoal experimentado pelo indivíduo desamparado na massa excitada. O delírio é produzido pelo descompasso entre as condições objetivas e a própria solução fascista. Quando não há ainda uma objetividade compatível, ou quando ela já está esgotada, a situação-limite do fascismo é fortalecida. Adorno diz que "com frequência ocorre que convicções e ideologias, justamente quando elas não são mais substanciais devido à situação objetiva, assumem então seu caráter demoníaco, seu caráter verdadeiramente destrutivo" (ADORNO, 2020, p. 48).

A função primordial da propaganda é despertar o "caráter demoníaco" que está latente e que pode se manifestar mediante a excitação política da massa. Seja como for, Adorno interpela a vitalidade do fascismo tendo o capitalismo histórico como condição dele, ou seja, "a concentração dominante de capital" é o pressuposto para as derivações políticas e sociais regressivas. Segundo ele, "essa tendência de concentração ainda significa a possibilidade da desclassificação permanente de camadas que eram completamente burguesas de acordo com sua consciência de classe subjetiva”. Mas qual o objetivo? Na verdade, as camadas burguesas "querem fixar seus privilégios e seu status social e possivelmente fortalecê-los" (ADORNO, 2020, p. 45-46).

No limite, temos uma disposição política orientada para a defesa intransigente da dominação social em estado puro. Assim, na incapacidade de encontrar uma solução para os problemas decisivos, ou mesmo na impossibilidade de elaborar uma imagem comum que identifique a causa do problema, o fascismo necessita operar uma distorção ideológica da realidade. Michela Murcia diz que "se há uma insatisfação difusa e o chefe ainda não encontrou uma solução, a melhor das banalizações estratégicas é dar ao povo um inimigo a quem atribuir culpa" (MURGIA, 20I9, p. 43). 
É assim que a criação do inimigo como espectro é necessária à ideologia do fascismo: a culpa é deslocada da causa para o efeito, produzindo um tipo de distorção poderosa e funcional à mobilização fascista:

Esses grupos continuam a tender a um ódio ao socialismo ou àquilo que eles chamam de socialismo, isto é, transferem a culpa de sua própria desclassificação potencial não ao aparato que a causa, mas àqueles que se opuseram criticamente ao sistema no qual outrora eles possuíam status, ao menos segundo concepções tradicionais (ADORNO, 2020, p. 46).

Com efeito, não podemos nos enganar, pois a vítima primordial do fascismo não é apenas o judeu. A culpa funciona como deslocamento do objeto autêntico para uma distorção que aparece como a verdade ideológica que ocupa diretamente seu lugar. A necessidade dos meios é diretamente proporcional à dispensabilidade dos fins. $\mathrm{O}$ inimigo quase sempre tem uma existência meramente espectral, pois - como prova do caráter delirante do fascismo - sua existência objetiva é irrelevante. Basta que sua existência se materialize no campo estritamente simbólico do imaginário ideológico para que ele tenha força objetiva. É isso que permite ao fascismo dar corpo ao inimigo em praticamente qualquer pessoa. Então, “o inimigo, por ter identidade genérica, pode ser confortavelmente acusado de qualquer coisa", o que possibilita que "as culpas de um único inimigo podem ser transferidas em bloco à categoria de pertencimento inteira" (MURCIA, 20I9, p. 52).

A atribuição da culpa pela desclassificação social é delirantemente deslocada da causa autêntica, ou seja, do capitalismo e sua dinâmica objetiva de funcionamento, para o efeito: rejeitados e dissidentes são, prioritariamente, objeto da constituição do espectro ideológico. É sua existência fantasmática que possibilita a eficácia do discurso de atribuição da culpa e, ao mesmo tempo, possibilita a mobilização de massas em torno do projeto de dominação social fascista. A questão é que o inimigo não é um outro qualquer, ele sempre está perto demais. Adorno e Horkheimer já haviam antecipado essa equação de maneira insuperável:

Só a cegueira do antissemitismo, sua falta de objetivo, confere uma certa verdade à explicação de que ele seria uma válvula de escape. A cólera é descarregada sobre os desamparados que chamam a atenção. E como as vítimas são intercambiáveis segundo a conjuntura: vagabundos, judeus, protestantes, católicos, cada uma delas pode tomar o lugar do assassino, na mesma volúpia cega do homicídio, tão logo se converta na norma e se sinta poderosa enquanto tal. Não existe um genuíno antissemitismo e, certamente, não há nenhum antissemita nato (ADORNO; HORKHEIMER, 2006, p. I42).

A noção ampla de antissemitismo é decisiva na compreensão das alterações ideológicas que ocorrem no momento de uma crise social mais aguda - o curto-circuito entre o conteúdo latente e o conteúdo manifesto da democracia - , que possibilita mudanças ideológicas radicais e alterações no equilíbrio de poder. $\mathrm{O}$ antissemitismo tem 
O inimigo quase

sempre tem uma

existência meramente

espectral, pois - como

prova do caráter

delirante do fascismo -

sua existência objetiva

é irrelevante. Basta

que sua existência

se materialize no

campo estritamente

simbólico do imaginário

ideológico para que ele

tenha força objetiva uma permanência indefinida sem conteúdo concreto definido - na democracia hoje, pois está completamente deslocado do seu objeto primordial. Talvez seja esse um dos aspectos que alimentam o negacionismo político atual, que rejeita qualquer alusão ao fascismo alegando se tratar de um fenômeno ultrapassado e preso ao passado. Pelo contrário, temos de considerar que "ele sobreviveu aos judeus, pode-se dizer, e daí vem a própria forma fantasmagórica" (ADORNO, 2020, p. 62).

A conclusão que podemos tirar aqui é que a forma espectral e fantasmagórica do antissemitismo representa a permanência assombrosa do fascismo na democracia. A eficácia do discurso da conspiração como espectro se realiza "por-

que o inimigo improvável é muito mais odiável do que aquele que podemos encontrar na padaria toda manhã" (MURGIA, 2019, p. 55). É sempre mais fácil acionar a existência de uma determinada monstruosidade latente que nos cerca e nos coloca em perigo permanente, embora jamais apareça inteiramente, do que realmente a identificar naquele sujeito que "podemos encontrar na padaria toda manhã". É a força do espectro.

Entretanto, o fascismo aparece no quadro mais amplo de crise do capitalismo e da democracia, mas todo acontecimento político se dá em uma conjuntura específica. Podemos dizer que são os interesses econômicos dominantes - obviamente, conjunturais - que definem a reação fascista? O fascismo que temos hoje não está fora da democracia, não está além dela, não pode ser encontrado aquém da dominação democrática, não pode ser sua antítese. Adorno afirma que o fascismo não é um movimento meramente conjuntural, pois seu nexo "com a economia é uma relação estrutural que existe naquela concentração e na tendência à pauperização", o que significa que "não pode ser imaginado tanto no curto prazo e, quando se equipara simplesmente radicalismo de direita com os movimentos de conjuntura, pode-se chegar a juízos bastante falsos" (ADORNO, 2020, p. 5I).

Precisamos considerar que "a conjuntura é antes de mais nada a determinação da instância dominante, cuja localização estabelece o ponto de partida da análise racional com o todo", ou seja, a relação entre conjuntura e estrutura descortina o fundamento real 
e objetivo do antagonismo decisivo. Alain Badiou segue dizendo que "a mudança da conjuntura [...] é identificável com a mudança de campo dominante” (BADIOU, I979, p. 2I, grifos originais).

Estamos experimentando hoje uma crise de hegemonia global, que pode ser traduzida pela mudança da conjuntura capaz de tensionar o próprio campo dominante. É o fascismo hoje dominante? Primeiro, precisamos pensar que o fascismo é uma reação virulenta que funciona buscando restaurar o capitalismo do seu fracasso. Badiou diz que o "monstro capitalista" age fundamentalmente "não por cada vez mais liberdade, mas por cada vez mais desigualdade", e que "o papel do Estado é o mesmo em toda parte: proteger essas desigualdades, proteger o monstro" (BADIOU, 2020, p. I7). Ao campo dominante:

[...] conservar um lugar, pequeno ou grande, no desenvolvimento do monstro, ou seja, ser ou tornar-se um jogador respeitado no frenesi internacional do mercado. Tendo por resultado que, pouco a pouco, a totalidade da oligarquia política, a totalidade da classe dirigente acaba por constituir um único grupo, um grupo de gente que, na verdade, é dividido pela competição pelos melhores lugares, mas que tem todo a mesma ideia quanto ao destino da humanidade. As grandes oposições tradicionais, republicanos contra democratas, direita contra esquerda, conservadores contra trabalhistas, tornaram-se puras abstrações, ligadas a uma época ultrapassada, pois essas pretensas divisões repousam, na verdade, na mesma convicção, na mesma base política e econômica. Todas essas divisões são atravessadas, minadas e finalmente anuladas por esse fato que qualquer político, qualquer governo, subscreve: sempre que está em jogo o futuro da humanidade, há apenas um partido, o do capitalismo (BADIOU, 2020, p. I8).

O campo dominante é a defesa intransigente do capitalismo, em que o imperativo é o aparecimento de pequenas diferenças que estão enquadradas no campo mais amplo da mesma orientação global: a impossibilidade de uma alternativa autêntica ao capitalismo. O exemplo da falsa antinomia substancial entre republicanos e democratas nos Estados Unidos é sintoma do enquadramento da rua de mão única instalado pelo capitalismo dominante.

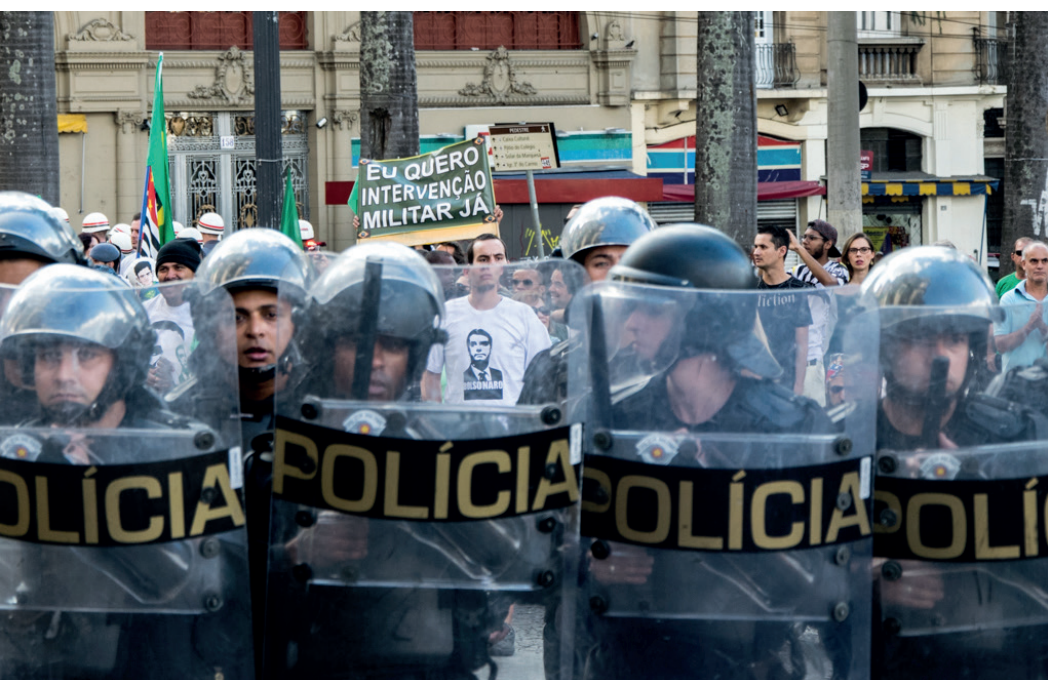

"Temos que considerar que o fascismo nunca foi realmente derrotado" 
É isso que fez Nancy Fraser constatar que o antagonismo está entre o "neoliberalismo progressista" e o "neoliberalismo reacionário" (FRASER, 2019, p. 37, 42), ou seja, a solução única é apenas uma variação do próprio capitalismo. Podemos ver aqui que o triunfo do capitalismo é marcado não pelas suas próprias virtudes, mas pela impossibilidade de que uma alternativa realmente factível (e realmente decisiva) se contraponha ao domínio hegemônico do capitalismo.

Nesse sentido, Alain Badiou diz que nos encontramos, "num certo sentido, num consenso", mas se trata de "um consenso negativo, é verdade, que não é um entusiasmo geral pelo capitalismo, mas o capitalismo não tem necessidade de um consenso afirmativo" (BADIOU, 2020, p. 39-40). A "normalidade" do capitalismo é interrompida por uma forma de regressão brutal, já que não temos hoje a possibilidade factível de uma alternativa emancipatória senão como potência radical transgressiva na forma da "esperança do mundo" (PINTO, 2020). Temos de considerar que o fascismo nunca foi realmente derrotado.

Talvez seja a esse sentido que se referiu Walter Benjamin quando falou na mobilização alemã da "guerra perdida" (BENJAMIN, 20II, p. 64). Na verdade, a derrota histórica do fascismo precisa aparecer como eliminação ideológica, mas, sobretudo, como impossibilidade objetiva. O que temos hoje é o ressurgimento do fascismo na dominação democrática capitalista como "fascismo democrático", uma designação paradoxal, mas realmente decisiva e capaz de capturar o elemento substancial do "novo radicalismo de direita” inscrito no nosso tempo. A caracterização de Badiou sobre Trump é sintomática:

Em Trump encontramos a vulgaridade deliberada, a relação patológica com as mulheres e o exercício calculado do direito de dizer publicamente coisas inaceitáveis para uma larga porção da humanidade. Exatamente como na Hungria, com Orbán, na Índia ou nas Filipinas, na Polônia ou na Turquia, com Erdoğan. Por toda a parte no mundo, somos então testemunhas desse fascismo democrático - intrínseco às práticas parlamentares da "democracia" capitalista moderna - que dá a impressão de uma novidade artificial, de uma linguagem diferente, de promessas violentas e, num certo sentido, de um interior externo, de qualquer coisa que se situa certamente no domínio da via única proposta por todos os governos do mundo, mas que orquestra tudo isso de uma maneira diferente daquela que oferecem os políticos clássicos, os quais se apoiam na burguesia culta. Desse modo, Trump e o seu bando produzem, no próprio interior do consenso capitalista global, um falso efeito de novidade. Ele é um pouco o enunciador alucinante de uma "nova via", mantendo-se tudo firmemente plantado na via da oligarquia dominante, culta ou não. Trump ocupa, de momento, uma posição que lhe permite proclamar ter qualquer coisa nova, ou seja, Trump - o nome e a coisa —, enquanto, se se olhar de perto, os seus propósitos, nacionalistas, sexistas, racistas e violentamente favoráveis à propriedade privada, são tudo menos novos (BADIOU, 202O, p. 2I-22). 
Ou seja, tem razão Nancy Fraser quando insiste que a variação entre uma posição ideológica reacionária e sua alternativa progressista - embora dentro do mesmo modelo neoliberal - não apenas desgastou o modelo dominante como possibilitou a abertura de uma crise hegemônica complexa. Ela diz que "nossa crise é global", envolve "um enfraquecimento dramático, se não um simples colapso, da autoridade dos partidos e das classes políticas estabelecidas". O que temos como resultado imediato é o surgimento de uma certa "melancolização" política e ideológica que faz com que a crença compartilhada no mundo e em suas instituições (políticas e apolíticas) derreta rapidamente no imaginário das pessoas comuns. Fraser diz que "na atual rejeição generalizada à política tradicional, uma crise objetiva do sistema como um todo encontrou sua voz política subjetiva” (FRASER, 20I9, p. 34-35).

O fascismo democrático é a nomeação e o enunciado da "voz política subjetiva" que responde à crise de hegemonia. Alain Badiou diz que há quatros figurações que exprimem a situação do mundo hoje: "o domínio estratégico do capitalismo global", "a decomposição da oligarquia burguesa tradicional”, "a agitação e a frustração dos povos" e "a falta de uma orientação, a fragilidade - digamos a palavra - da hipótese comunista" (BADIOU, 2020, p. 26). Precisamos dizer que a ausência de uma orientação política de oposição radical ao capitalismo é, na verdade, a preponderância de um tipo de sujeição pelo qual o gozo está colonizado. Uma crítica transformativa consistente - que funcionaria como uma forma de transgressão política, social e ideológica - será aquela capaz de produzir uma forma de gozo que nos descolonize da sujeição que nos mantém aprisionados no capitalismo existente, possibilitando a abertura de uma autêntica e nova "voz política subjetiva" emancipatória.

\section{CONCLUSÃO: O GOZO PARA FORA DO CAPITALISMO}

O ponto fundamental é que a inexistência de outra orientação política é, de alguma maneira, responsável pela produção do fascismo democrático. Na ausência de uma alternativa autêntica, não alienada e libertadora, a crise de hegemonia encontra sua solução na orientação alienada à causa dissimulada. Slavoj Žižek é ainda mais impiedoso, pois constata "o desaparecimento da esquerda radical de nossa realidade política e ideológica: os sobreviventes da antiga esquerda radical são como simpáticos mortos-vivos, remanescentes de uma antiga era, estranhos à deriva em um estranho mundo" (ŽIŽEK, 20I4, p. I3). De fato, trata-se de uma enunciação dolorosa, pois ele não diz que a esquerda desapareceu empiricamente, mas sugere que o desaparecimento da esquerda como orientação alternativa ao capitalismo e ao fascismo democrático tem como consequência imediata a permanência da nossa forma de vida.

$\mathrm{O}$ antagonismo decisivo é aquele que contrapõe formas de vida, ou melhor, mundos alternativos. A questão importante é que a contradição hoje somente é permitida quando representar uma variante do mesmo mundo dominante: a mudança está reduzida ao controle do campo dominante e não à dominação em si, ou seja, é como se 
a substituição da personificação do poder dominante alterasse a substância do objeto que constitui o próprio poder da dominação. A luta pelo governo do mundo se realiza por um embate de diferenças que não dão corpo a alternativas opostas entre mundos. Isso significa que o fascismo democrático é uma forma de despolitização, pois não temos vias alternativas, mas apenas variantes do mesmo modelo de mundo. A política é justamente o tipo de ação coletiva capaz de instaurar um acontecimento verdadeiramente político. Ela produz desentendimento. Nesse caso, a politização é aquilo que produz processos transformativos duradouros.

Podemos insistir na ideia de que "no capitalismo, é possível dizer que não é possível nada diferente" (BADIOU, 2020, p. 38). É por isso que não podemos permitir que o sistema dominante seja responsável pela criação da "nossa revolução", dos enunciados da nossa mudança. Já sabemos que o capitalismo (assim como o fascismo democrático) produz formas particulares de sujeição e de satisfação na forma do gozo. Não podemos nos contentar em mudar o controle da "objetividade" existente e deixar à deriva a própria "objetividade" (fetichista) intacta. É necessário criar uma outra objetividade e, em consequência, outra forma de subjetividade e de satisfação, na forma de gozo descolonizado. O fascismo democrático hoje atua agindo pela colonização do desejo, sobre suas formas de satisfação e gozo.

No entanto, o que a psicanálise nos ensina — sobretudo a clínica de Lacan — é que "nossa única alternativa é retirar tal gozo para fora do modo de produção que o coloniza" (SAFATLE, 2020, p. 69). Não podemos esquecer que a crítica da economia política deve vir acompanhada de uma crítica da economia libidinal, pois a superação da exploração é impotente quando não está acompanhada da superação da sujeição que coloniza o gozo. Isso não será possível sem que a verdadeira contradição seja restituída mediante a instauração de um processo verdadeiramente criativo e transformativo:

Devemos, se possível, criar um regresso a uma verdadeira contradição. É essa a lição a tirar da coisa horrível que ontem aconteceu na noite profunda. A nossa tarefa é, agora, construir uma orientação política que irá largamente para lá das leis do mundo tal como ele é, e isso assumindo o risco de que na partida as coisas possam não ser claras, e até mesmo se apresentem como impossíveis. É momento de relembrar aqui a fórmula de Lacan segundo a qual "o real é impossível". Devemos voltar à verdadeira contradição entre política a serviço do capitalismo e política a serviço dos povos [...]. Não é suficiente criticar, negar, resistir. A nossa tarefa é afirmar um novo começo (BADIOU, 2020, p. 30).

Para isso, pois, é necessário que uma orientação política alternativa não seja uma mera política da nomeação e da identificação. Ao contrário, uma política transformativa precisa se pautar pela desnomeação e pela desidentificação com os lugares existentes. O que o fascismo democrático busca reinstituir é a ordem dos lugares e 
suas nomeações regressivas. Podemos aprender com as experiências do fascismo democrático hoje que o colapso não é garantia imediata da produção de processos transformativos, mas abre a possibilidade de uma regressão social ainda mais radical e profunda. Enquanto o fascismo democrático apresenta o que é propriamente possível — isto é, a restauração das hierarquias e desigualdades capitalistas —, uma alternativa política transformativa institui a ordem do que é impossível no campo simbolizável da ideologia, pois subverte a localização dos lugares e a ordem das nomeações e identificações subjacentes.

É por isso que Vladimir Safatle, seguindo o caminho inaugurado por Lacan, insiste que "a política emancipa quando nos leva a nos identificar com um lugar vazio que permite a consolidação igualitária que dissolve os efeitos do grupo (com suas estereotipias e exclusões), assim como a circulação do poder" (SAFATLE, 2020, p. 54). O fascismo ocupa o lugar vazio do poder, instaurando a encarnação de modalidades brutais de exclusão e violência na produção do sujeito que pode ser amparado pelo próprio poder dominante. Paradoxalmente, a alternativa ideológica não é disputarmos a ocupação do vazio do poder com o fascismo, mas permitir que sua própria vacuidade decisiva apareça. Nesse sentido, o vazio é uma resposta possível (e necessária) ao fascismo.

Para uma orientação alternativa, é muito importante compreender os mecanismos complexos de sujeição. O gozo está colonizado por um objeto primordial que é produzido pela falta permanente. De alguma maneira, podemos dizer que a economia política e a economia libidinal estão separadas e não podem produzir — pelas suas próprias imanências - nenhuma alternativa ideológica vigorosa. Somente com a unificação das críticas econômica e libidinal, ou melhor, mediante uma crítica libidinal da economia e uma crítica econômica do desejo, é que talvez possamos elaborar uma alternativa global e transformativa ao capitalismo. Com efeito, a indisposição contra o fascismo é uma orientação simbolizável que possibilita a instauração de um gozo que nos empurre para fora do capitalismo. Ou desejamos seguir com nosso gozo colonizado pela delirante fantasmagoria (paranoica) fascista? Talvez seja essa a verdadeira pergunta do nosso tempo. É necessário coragem para fazê-la. É indispensável a tessitura do desejo para encontrar uma solução transgressora e emancipatória. Como diz Badiou, "a nossa tarefa é afirmar um novo começo".

\footnotetext{
* Doutor em Políticas Públicas e professor adjunto do Departamento de Economia da Universidade Federal do Maranhão (UFMA). É autor de Esperança do mundo: ontologia, futuro e emancipação no século 21, pela editora Lumen Juris (2020).E-mail: saulo.pinto@ufma.br
}

Texto recebido em fevereiro de 2021; aprovado em março de 2021 
ADORNO, Theodor W. Aspectos do novo radicalismo de direita. São Paulo: Editora Unesp, 2020.

. Mínima moralia. Rio de Janeiro: Beco do Azougue, 2008.

; HORKHEIMER, Max. Dialética do esclarecimento. Rio de Janeiro: Zahar, 2006.AGAMBEN,

Giorgio. Estado de exceção. São Paulo: Boitempo, 2004.

BADIOU, Alain. Trump. Lisboa: VS Editor, 2020.

. O (re) começo do materialismo dialético. In: BADIOU, Alain; ALTHUSSER, Alain. Materialismo

histórico e materialismo dialético. São Paulo: Global, 1979.

BENJAMIN, Walter. Teorias do fascismo alemão: sobre a coletânea Guerra e guerreiros, editada por Ernest Jünger. In:

Magia e técnica, arte e política: ensaios sobre literatura e história da cultura. São Paulo: Brasiliense, 2011

DI CESARE, Donatella. Vírus soberano?: a asfixia capitalista. Belo Horizonte; Veneza: Editora Âyiné, 2020.

FISHER, Mark. Realismo capitalista: é mais fácil imaginar o fim do mundo do que o fim do capitalismo?. São Paulo: Autonomia Literária, 2020.

FRASER, Nancy. O velho está morrendo e o novo não pode nascer. São Paulo: Autonomia Literária, 2019.

2020.

; JAEGGI, Rahel. Capitalismo em debate: uma conversa na teoria crítica. São Paulo: Boitempo,

GORDON, Peter E. Adorno e o neofascismo. A Terra É Redonda, 10 jan. 2021. Disponível em: <https://aterraeredonda.com.br/adorno-e-o-neofascismo>. Acesso em: 30 jan. 2021.

HARARI, Yuval Noah. Homo Deus: uma breve história do amanhã. São Paulo: Companhia das Letras, 2016.

HEGEL, Georg Wilhelm Friedrich. Linhas fundamentais da filosofia do direito ou Direito natural e ciência do estado em compêndio. São Leopoldo: Unisinos, 2010.

Principios de la filosofía del derecho. Barcelona: Edhasa, 1999.

KURZ, Robert. A democracia devora seus filhos. Rio de Janeiro: Consequência, 2020.

LACLAU, Ernesto. Política e ideologia na teoria marxista: capitalismo, fascismo e populismo. Rio de Janeiro: Paz e Terra, 1979.

LAZZARATO, Maurizio. Fascismo ou revolução?: o neoliberalismo em chave estratégica. São Paulo: N-1 Edições, 2019.

MARX, Karl. Sobre a questão judaica. São Paulo: Boitempo, 2010.

MURGIA, Michela. Instruções para se tornar um fascista. Belo Horizonte; Veneza: Editora Âyiné, 2019.

PACHUKANIS, Evguiéni B. Fascismo. São Paulo: Boitempo, 2020.

PINTO, Saulo. Esperança do mundo: ontologia, futuro e emancipação no século 21. Rio de Janeiro: Lumen Juris, 2020.

PRECIADO, Paul. Aprendendo com o vírus. Punkto, 9 abr. 2020. Disponível em: <www.revistapunkto. com/2020/04/aprendendo-com-o-virus-paul-b-preciado.html>. Acesso em: 20 de janeiro de 2021.

RANCIÈRE, Jacques. O desentendimento. São Paulo: Editora 34, 2018.

O ódio à democracia. São Paulo: Boitempo, 2014.

SAFATLE, Vladimir. Maneiras de transformar mundos: Lacan, política e emancipação. Belo Horizonte: Autêntica, 2020.

Um dia, esta luta iria ocorrer. São Paulo: N-1 Edições, 2018.

ŽIŽEK, Slavoj. Como ler Lacan. Rio de Janeiro: Zahar, 2010.

Elogio da intolerância. Lisboa: Relógio D’Água, 2006.

Menos que nada: Hegel e a sombra do materialismo histórico. São Paulo: Boitempo, 2013.

O verdadeiro golpe de Trump. Blog da Boitempo, 14 jan. 2021. Disponível em: <https:// blogdaboitempo.com.br/2021/01/14/zizek-o-verdadeiro-golpe-de-trump>. Acesso em: 20 jan. 2021.

Violência: seis reflexões laterais. São Paulo: Boitempo, 2014. 